\title{
Impact of Socially Responsible Leadership on Employee Leave Intention: Exploratory Study on IT Companies in Egypt
}

\author{
Mona Arishi ${ }^{1}$, Abdel Moniem Elsaid ${ }^{2}$, Sahar Dawi $^{3}$ \& Eahab Elsaid ${ }^{3}$ \\ ${ }^{1}$ Client Centre Leader, IBM Middle East \& Africa \\ ${ }^{2}$ Faculty of Commerce, Ain Shams University \\ ${ }^{3}$ Odette School of Business, University of Windsor, USA \\ Correspondence: Eahab Elsaid, Odette School of Business, University of Windsor, USA
}

Received: April 4, 2018

doi:10.5430/bmr.v7n2p17
Accepted: April 16, 2018

Online Published: April 30, 2018

\begin{abstract}
The study examines the impact of Socially Responsible Leadership on Employee Leave Intention in IT companies in Egypt. The sample consists of 208 employees in Egyptian IT companies. The study used the updated version of the Socially Responsible Leadership Scale (SRLS-R2) as the tool of investigation. The methodology used included the Pearson coefficient, the Cronbach Alpha coefficient, simple liner regressions and ANOVA tests. The study concluded that Socially Responsible Leadership and its eight dimensions (Congruence, Commitment, Common Purpose, Collaboration, Controversy with Civility, Citizenship, Change for the Common Good and Consciousness of Self) have a significant negative impact on the Employee Leave Intention.
\end{abstract}

Keywords: socially responsible leadership, employee leave intention, IT sector, Egypt

\section{Introduction}

Employee turnover is a major challenge for today's organizations. Most organizations will experience turnover in some capacity. In fact, O'Connell and Mei-Chuan (2007) reported the average cost of employee turnover to be $\$ 13,996$ per employee. Hom and Griffeth (1995) concede that since employees are considered to be an essential organizational resource, the costs associated with their turnover, the resultant hiring of replacement employees, loss of productivity, time to acclimate to the organizational culture, the onboarding process for the new personnel and overall administration costs can be taxing on the organization. Long and Thean (2011) indicate that since employees work interdependently in organizations, the turnover of some employees will affect the overall efficiency of the remaining employees. It is important to understand the causes of voluntary turnovers and what can be done in order to reduce them. Therefore, turnover of employees poses a significant threat to organizations, which necessitates a deeper look at its causes and effects.

Dawley et al. (2010) found that organizational leaders/supervisors who manage to create and implement processes aimed at employee retention which reduce voluntary turnover will have an advantage over those leaders who do not. Maertz et al. (2007) found that the leader/supervisor and organizational perceived support is an indicator and predictor of employee turnover intention. Allen et al., (2003) and Rhoades and Eiseberger (2002) find that leader and organizational support can lead to a reduction in employee turnover.

Previous research focused on examining and describing turnover predictors, such as job satisfaction and organizational commitment, which are linked to turnover behavior and turnover intention (Griffeth et al., 2000). However, it is important to point out that turnovers could have positive effects on an organization. It is healthy for the organization to fire the employees who are unproductive and replace them with the productive employees who will increase the human capital and introduce innovative ideas and solutions. Hughes et al. (2010) find that minor turnover is healthy for the organization in order to help reduce conflicts and bring about change and innovation.

We organize the remainder of the paper as follows. Section 2 reviews past literature on Employee Turnover, Socially Responsible Leadership, and the Socially Responsible Leadership Scale. In section 3 we discuss the data and sample. In section 4 we discuss the methodology. In section 5 we discuss our hypotheses and results. Section 6 concludes. 


\section{Literature Review}

\subsection{Employee Turnover}

Bluedorn (1978) defines voluntary turnover as "the process by which an employee willingly and voluntarily terminates membership of the organization." Dissatisfaction with the work environment influences employee turnover, which reduces contributions to the job, and ultimately impacts employee decisions to leave (AlBattat and Som, 2013). While employees leave their positions for numerous reasons, leave intention is a topic that has been studied from many perspectives in organizational literature. It is therefore necessary to identify the antecedents of turnover behavior in hopes of understanding and controlling it (Vandenberg and Nelson, 1999). Turnover intention, defined by Tett and Meyer (1993) as a "conscious and deliberate willingness to leave the organization", is commonly regarded as the most significant predictor of actual turnover.

Turnover intention can be affected by several factors, such as job stress, organizational commitment, job satisfaction and support from a direct supervisor (Siong et al., 2006). Leadership appears to have a major impact on voluntary turnover. In fact, leadership has been one of the most recognized causes of turnover (Abbasi and Hollman, 2000; Griffith, 2003; Kleinman, 2004; Mobley, 1982; Price, 2001). The concept that leadership is somehow related to employee turnover has been examined by several studies that investigated the relationship of employees' perceptions of their leaders and the employees' turnover intention. One of those studies is Abbasi and Hollman (2000) who find that a leader's functional background and previous experience can have an effect on employee leave intention, forming an inverse relationship between the employees' perceptions of leaders and turnover intention (Hsu et al., 2003; Hughes et al., 2010; Long and Thean, 2011; Long et al., 2012; Wells and Peachey, 2010). Maertz et al. (2007) state that "Although much of the subsequent research has focused on attitudinal (e.g., satisfaction) and tangible (e.g., pay) inducements to stay, a growing body of work recognizes that relational inducements such as support from the organization and from a supervisor can also play an important role in such decisions (e.g., Allen, Shore, \& Griffeth, 2003)."

\subsection{Socially Responsible Leadership}

In recent times, studies have shifted their gaze to the ethics and responsibilities of leaders after news of widespread corporate scandals and managerial misconduct. Maak and Pless (2006) proposed that organizational leaders should alter the age old managerial concept of shareholder primacy and instead seek benefits for all stakeholders as a way of fulfilling their corporate social responsibility.

Prevailing leadership theories focus on the relationship between the leader and employee, ignoring the influence of the leaders' behaviors and decisions on other beneficiaries - such as stakeholders - with the exception of shareholders. Subsequently, there was a need for a different view of leadership. Maak (2007) proposed the concept of Responsible Leadership as a way to alleviate the previous theoretical deficiencies, achieve harmony between the conflicting interests among stakeholders inside and outside the firm, and gain the public trust while achieving sustainable development. Maak (2007) describes responsible leadership as leadership that "contributes to building social capital and ultimately to both a sustainable business and the common good." It is the kind of leadership that is beneficial to many stakeholders (not just the shareholders who are willing to accept risk in exchange for a high return on their investments). The idea behind responsible leadership is that it facilitates the building of mutually beneficial relationships with multiple stakeholders in order to create goodwill and trust from the stakeholders towards the corporations.

Komives and Wagner (2009) define Socially Responsible Leadership as a "purposeful, collaborative, values- based process that results in positive social change." This definition is consistent with the Contemporary Leadership Theory, which represents a shift from the focus on management and production towards a focus on the common good, reciprocal relationships and social justice (Komives and Dugan, 2010; Northouse, 2012).

\subsection{The Socially Responsible Leadership Scale}

Tyree (1998) is credited with developing the Socially Responsible Leadership Scale (SRLS), a survey that is designed to determine the leadership qualities of college students. The 103-item tool of the SRLS measures the seven "C"s relating to student leadership development as determined by the Social Change Model (SCM): consciousness of self, congruence, commitment, collaboration, common purpose, controversy with civility, and citizenship in addition to a scale related to change for the common good. Future versions of the instrument did not include the scale for change. Other researchers have since refined the instrument, and the updated version is known as the SRLS-R2, the scale used in the current study. The SRLS-R2 has been used independently (Foreman and Retallick, 2012), and as a component of the Wabash National Study, a six-year longitudinal study to assess critical factors affecting the 
leadership outcomes of a liberal arts education (Hu and McCormick, 2012; Pascarella and Blaich, 2013; Rosch and Caza, 2012).

\subsection{Objectives and Contributions of the Study}

The main objective of our study is to contribute to the ever growing stream of turnover research. More specifically, we are trying to zero in on the effect socially responsible leadership on employee turnover intention and behavior. There is wide spread agreement on the negative effects of high voluntary turnover rates on firm performance, firm efficiency and employee morale. Many previous studies have examined ways to reduce turnover rates. However, most of this research was done in North America and Europe. Our objective is to conduct turnover research in Egypt which lies in a geographical location that has not been adequately examined in the past.

Ethical tools can be a powerful means of enhancing organizational delivery and retaining talent. While Codes of Conduct and Integrity Practices have become part of many organizations' DNA, we still find a high rate of employee turnovers threatening many institutions. For this reason, the topic has become a vital one to explore. The contributions of the study over existing literature on the topic are as follows: As the business landscape emerges into a new era of high-technology needs, information technology personnel grow in demand. The retention of IT professionals, who are in very high demand in today's corporate world, has surprisingly received little attention (Ertürk and Vurgun, 2015). In fact, the IT sector faces very high turnover rates, a fact that is not commonly discussed or explored. Our study attempts to address a gap in the literature regarding the retention of talent in an ever-growing technology sector.

Secondly, while there is a significant amount of previous research on the topic of employee leave intention and socially responsible leadership, our work focuses on these variables in the context of the IT industry set in an African/Middle-Eastern country; Egypt. To the best of our knowledge, this is one of the first studies to test these variables against this sector and geographical location. Our findings create a unique opportunity to compare future results against not only industry boundaries, but cultural ones as well. This opens the discussion to additional factors which may influence employee leave intention and highlights the possible nuances that culture and geographical location may create. Finally, the significant correlation highlighted in this study between socially responsible leadership and employee leave intention offers a possible guideline to alleviating high rates of turnover in the IT sector.

\section{Data Collection and Sample}

\subsection{Study Sample}

The study focuses on employees working in IT companies in Egypt. The study sample consists of 250 employees of IT companies. The sample was selected according to the method of convenience. The number of respondents was determined by analyzing a random experiential sample consisting of 50 employees. It was found that the average standard deviation of their manager's qualifications equals 0.42346. After that, the required sample size was calculated on the basis of confidence level $95 \%$ and permitted error by 0.05 , as follows :

$$
\mathrm{n}=\frac{\mathrm{z}^{2} * \mathrm{~s}^{2}}{\mathrm{e}^{2}}(\text { Yamane, 1967: 581) }
$$

where:

e: allowable error,

s: standard deviation of the sample,

$\mathrm{n}$ : the required sample size.

z: the level of confidence expressed in standard degrees.

Two hundred and fifty forms were distributed to a group of employees of IT companies in Egypt, from the beginning of June 2016 until the end of September 2016. Two hundred and sixteen forms were returned. Eight forms were incomplete and unfit for statistical analysis, so they were excluded. As a result, there were 208 forms valid for statistical analysis, with an average of $83.2 \%$ of the total distributed questionnaires. We used all 208 forms in our analysis.

\subsection{Research Tool}

The questionnaire was divided into three parts as follows:

\subsubsection{Socio-Demographic Data}

Socio-Demographic Data includes the manager's: gender, qualification, department specification, years of experience, 
managerial level and organization size.

3.2.2 Socially Responsible Leadership Dimensions.

Socially Responsible Leadership Dimensions include (8) dimensions and consists of (68) statements as follows:

- First dimension: Congruence and it consists of seven statements (Numbers 13, 27, 32, 52, 64, 65, 69).

- Second dimension: Commitment and it consists of six statements (Numbers 23, 24, 28, 51, 53, 54).

- Third dimension: Common Purpose and it consists of nine statements (Numbers 15, 14, 19, 31, 35, 37, 58, $61,68)$.

- Fourth dimension: Collaboration and it consists of eight statements (Numbers 10, 29, 30, 42, 48, 57, 60, 66).

- Fifth dimension: Controversy with Civility and it consists of eleven statements (Numbers 1, 2, 3, 5, 7, 11, 16, $21,25,49,62)$.

- Sixth dimension: Citizenship and it consists of eight statements (Numbers 33, 38, 40, 44, 46, 55, 67).

- Seventh dimension: Change for the Common Good and it consists of ten statements (Numbers 8, 12, 17, 20, $26,36,39,43,45,50)$.

- Eighth dimension: Consciousness of Self and it consists of nine statements (Numbers 4, 6, 9, 18, 22, 34, 41, $56,59)$.

\subsubsection{Employee Leave Intention}

Employee Leave Intention consists of one dimension and it consists of six statements (Numbers 63, 70, 71, 72, 73, 74).

\subsection{Data Collection Instrument and Source}

\subsubsection{Questionnaire}

The used questionnaire consists of seventy four statements, scaled on a 5-point Likert scale, ranging from "Strongly Disagree" to "Strongly Agree".

Table 1. Likert Scale

\begin{tabular}{lccccc}
\hline Reply & $\begin{array}{c}\text { Strongly } \\
\text { Disagree }\end{array}$ & Disagree & $\begin{array}{c}\text { Neither Agree } \\
\text { nor Disagree }\end{array}$ & Agree & $\begin{array}{c}\text { Strongly } \\
\text { Agree }\end{array}$ \\
\hline Degree & 1 & 2 & 3 & 4 & 5 \\
\hline
\end{tabular}

These answers were classified into five equal-range levels by the following equation:

Category Length $=($ the largest value - the lowest value $) \div$ number of measure alternatives $=(5-1) \div 5=0.80$

To get the following value of weighted means of each description or alternative:

Table 2. Distribution of Means According to the Hierarchy Used in the Research Tool

\begin{tabular}{cc}
\hline Description & Weighted Mean Value \\
\hline Strongly Agree & from 4.2 to 5 \\
Agree & from 3.4 to less than 4.2 \\
Neither Agree nor Disagree & from 2.6 to less than 3.4 \\
Disagree & from 1.8 to less than 2.6 \\
Strongly Disagree & from 1 to less than 1.8 \\
\hline
\end{tabular}

\section{Methodology}

The Pearson coefficient was used to measure the validity of the questionnaire, the Cronbach Alpha coefficient to determine the reliability of the questionnaire, simple linear regression models to test the hypothesis and ANOVA test to examine the significance of the proposed simple linear regression models.

\subsection{Descriptive Statistics}

\subsubsection{Gender}

The number of male managers $(n=130)$ represents $62.5 \%$ of the sample. The number of female managers $(n=78)$ represents $37.5 \%$ of the sample. 


\subsubsection{Qualifications}

The number of managers who graduated from college $(n=118)$ represents $56.7 \%$ of the sample. The number of managers who obtained post graduate degrees $(n=90)$ represents $43.3 \%$ of the sample.

\subsubsection{Manager Experience}

The number of managers' years of experience $(<5$ years $)(n=6)$ represents $2.9 \%$ of the sample, from $(5-10$ years $)$ $(n=28)$ represents $13.5 \%$ of the sample and $(>10$ years $)(n=174)$ represents $83.7 \%$ of the sample.

\subsubsection{Managerial Level}

The number of First Line Managers $(n=68)$ represents $32.7 \%$ of the sample, the number of Middle Managers $(n=42)$ represents $20.2 \%$ of the sample and the number of Executives $(n=98)$ represents $47.1 \%$ of the sample.

\subsubsection{Organization Size}

The number of employees working in the organization ( $<50$ employees) $(n=52)$ represents $2.9 \%$ of the sample, $(50-$ 200 employees $)(n=26)$ represents $13.5 \%$ of the sample and $(>200$ employees $)(n=130)$ represents $62.5 \%$ of the sample.

4.1.6 Questionnaire Statements on the Socially Responsible Leadership Dimensions

Provided in the Appendix.

4.1.7 Questionnaire Statements on the Employee Leave Intention

Provided in the Appendix.

\section{Hypotheses Development and Results}

The Bivariate Correlation test was used to analyze the data. It measures the Pearson correlation coefficient and examines the relationship between variables. The Pearson correlation coefficient is considered to be a measure of linear association. The correlation coefficient value (r) with a range from 0.10 to 0.29 is considered weak, from 0.30 to 0.49 is considered medium and from 0.50 to 1.0 is considered strong.

Table 3. Correlation between Socially Responsible Leadership and Employee Leave Intention

\begin{tabular}{|c|c|c|c|c|c|c|c|c|c|c|}
\hline & ELI & SRL & 1 & 2 & 3 & 4 & 5 & 6 & 7 & 8 \\
\hline ELI & 1 & & & & & & & & & \\
\hline SRL & $-0.420^{* *}$ & 1 & & & & & & & & \\
\hline 1 & $-0.4329^{* *}$ & $0.883^{* *}$ & 1 & & & & & & & \\
\hline 2 & $-0.278^{* *}$ & $0.850^{* *}$ & $0.790^{* *}$ & 1 & & & & & & \\
\hline 3 & $-0.385^{* *}$ & $0.924^{* *}$ & $0.823^{* *}$ & $0.744^{* *}$ & 1 & & & & & \\
\hline 4 & $-0.375^{* *}$ & $0.927^{* *}$ & $0.828^{* * *}$ & $0.796^{* *}$ & $0.888^{* *}$ & 1 & & & & \\
\hline 5 & $-0.348^{* *}$ & $0.746^{* *}$ & $0.561^{* *}$ & $0.527^{* * *}$ & $0.614^{* *}$ & $0.605^{* *}$ & 1 & & & \\
\hline 6 & $-0.360^{* *}$ & $0.888^{* *}$ & $0.791^{* *}$ & $0.719^{* * *}$ & $0.835^{* *}$ & $0.866^{* *}$ & $0.542^{* *}$ & 1 & & \\
\hline 7 & $-0.408^{* * *}$ & $0.828^{* *}$ & $0.668^{* *}$ & $0.663^{* *}$ & $0.717^{* *}$ & $0.719^{* * *}$ & $0.641^{* *}$ & $0.716^{* *}$ & 1 & \\
\hline 8 & $-0.303^{* *}$ & $0.753^{* *}$ & $0.615^{* *}$ & $0.648^{* *}$ & $0.627^{* *}$ & $0.628^{* *}$ & $0.536^{* *}$ & $0.593^{* *}$ & $0.529^{* * *}$ & 1 \\
\hline
\end{tabular}

* significance at the (0.05) level (two-tailed), ** significance at the (0.01) level (two-tailed)

ELR: Employee Leave Intention; SRL: Socially Responsible Leadership; Dimension 1: Congruence; Dimension 2:

Commitment; Dimension 3: Common Purpose; Dimension 4: Collaboration; Dimension 5: Controversy with Civility; Dimension 6: Citizenship; Dimension 7: Change for the Common Good; Dimension 8: Consciousness of Self

Table 3 shows that the correlation between Socially Responsible Leadership (SRL) and Employee Leave Intention (ELI) ratings were medium $(-0.420, \mathrm{P}<0.01)$. As a result, our first hypothesis indicates that:

H1: There is significant negative impact for the Socially Responsible Leadership on the Employee Leave Intention.

To examine the effect of Socially Responsible Leadership on Employee Leave Intention, we use the simple linear regression analysis: 
Table 4.

Panel A. Simple Linear Regression of Socially Responsible Leadership on Employee Leave Intention

\begin{tabular}{ccccc}
\hline Model & $\mathrm{R}$ & $\mathrm{R}^{2}$ & Adjusted $\mathrm{R}^{2}$ & $\begin{array}{c}\text { Std. Error of the } \\
\text { Estimate }\end{array}$ \\
\hline 1 & 0.420 & 0.177 & 0.173 & 0.60523
\end{tabular}

Panel B. ANOVA Test to Examine the Overall Proposed Simple Linear Regression Model for the Socially Responsible Leadership and Employee Leave Intention

\begin{tabular}{lccccc}
\hline Model & Sum of Squares & df & Mean Square & F & Sig. \\
\hline Regression & 16.183 & 1 & 16.183 & 44.179 & 0.000 \\
Residual & 75.458 & 206 & 0.366 & & \\
Total & 91.641 & 207 & & &
\end{tabular}

Panel C. T- test to Examine the Significance of the Coefficients in the Simple Linear Regression Model for the Socially Responsible Leadership and Employee Leave Intention.

\begin{tabular}{|c|c|c|c|c|c|}
\hline \multirow[b]{2}{*}{ Model } & \multicolumn{2}{|c|}{$\begin{array}{l}\text { Unstandardized } \\
\text { Coefficients }\end{array}$} & \multirow{2}{*}{$\begin{array}{c}\begin{array}{c}\text { Standardized } \\
\text { Coefficients }\end{array} \\
\text { Beta }\end{array}$} & \multirow[t]{2}{*}{$\mathrm{T}$} & \multirow[t]{2}{*}{ Sig. } \\
\hline & $\mathrm{B}$ & Std. Error & & & \\
\hline Constant & 4.517 & 0.260 & & 17.338 & 0.000 \\
\hline Socially Responsible Leadership & -0.490 & 0.074 & -0.420 & -6.647 & 0.000 \\
\hline
\end{tabular}

Table 4 Panel A shows that the Adjusted $\mathrm{R}^{2}$ is 0.173 , which means that the independent variable (Socially Responsible Leadership) interprets $17.3 \%$ of the changes occurring in the dependent variable (Employee Leave Intention). Table 4 Panel B shows a statistically significant relationship between the independent variable (Socially Responsible Leadership) and the dependent variable (Employee Leave Intention) which confirms the high explanatory power of the simple linear regression model statistically. Table 4 Panel $\mathrm{C}$ shows that the independent variable (Socially Responsible Leadership) is significant and negatively related to the dependent variable (Employee Leave Intention). Therefore, we accept H1 stipulating that there is significant negative impact for the Socially Responsible Leadership on the Employee Leave Intention.

Using the unstandardized coefficients we can present the regression equation as follows:

$$
\text { Employee Leave Intention }=4.517+(-0.490) \text { (Socially Responsible Leadership) }
$$

\subsection{The Impact of Congruence on Employee Leave Intention}

Table 3 shows that the correlation between Congruence (Dimension 1) on Employee Leave Intention (ELI) ratings were medium $(-0.4329, \mathrm{P}<0.01)$. As a result, our second hypothesis indicates that:

H2: There is significant negative impact for Congruence on the Employee Leave Intention.

To examine the effect of Congruence on Employee Leave Intention, we use the simple linear regression analysis:

Table 5 .

Panel A. Simple Linear Regression of Congruence on Employee Leave Intention

\begin{tabular}{ccccc}
\hline Model & $\mathrm{R}$ & $\mathrm{R}^{2}$ & Adjusted $\mathrm{R}^{2}$ & $\begin{array}{c}\text { Std. Error of the } \\
\text { Estimate }\end{array}$ \\
\hline 1 & 0.329 & 0.108 & 0.104 & 0.42136 \\
\hline
\end{tabular}

Panel B. ANOVA Test to Examine the Overall Proposed Simple Linear Regression Model for Congruence and Employee Leave Intention

\begin{tabular}{lccccc}
\hline Model & Sum of Squares & df & Mean Square & F & Sig. \\
\hline Regression & 4.447 & 1 & 4.447 & 25.047 & 0.000 \\
Residual & 36.574 & 206 & 0.178 & & \\
Total & 41.021 & 207 & & & \\
\hline
\end{tabular}


Panel C. T- test to Examine the Significance of the Coefficients in the Simple Linear Regression Model for Congruence and Employee Leave Intention.

\begin{tabular}{lcccccc}
\hline \multirow{2}{*}{ Model } & \multicolumn{2}{c}{$\begin{array}{c}\text { Unstandardized } \\
\text { Coefficients }\end{array}$} & $\begin{array}{c}\text { Standardized } \\
\text { Coefficients }\end{array}$ & \multirow{2}{*}{$\mathrm{T}$} & \multirow{2}{*}{ Sig. } \\
\cline { 2 - 4 } Constant & $\mathrm{B}$ & Std. Error & Beta & & \\
\hline Congruence & 1.667 & 0.139 & & 11.998 & 0.000 \\
\cline { 1 - 5 } & -0.181 & 0.036 & -0.329 & -5.005 & 0.000
\end{tabular}

Table 5 Panel A shows that the Adjusted $\mathrm{R}^{2}$ is 0.104 , which means that the independent variable (Congruence) interprets $10.4 \%$ of the changes occurring in the dependent variable (Employee Leave Intention). Table 5 Panel B shows a statistically significant relationship between the independent variable (Congruence) and the dependent variable (Employee Leave Intention) which confirms the high explanatory power of the simple linear regression model statistically. Table 5 Panel $\mathrm{C}$ shows that the independent variable (Congruence) is significant and negatively related to the dependent variable (Employee Leave Intention). Therefore, we accept H2 stipulating that there is significant negative impact for Congruence on the Employee Leave Intention.

\subsection{The Impact of Commitment on Employee Leave Intention}

Table 3 shows that the correlation between Commitment (Dimension 2) on Employee Leave Intention (ELI) ratings were medium $(-0.278, \mathrm{P}<0.01)$. As a result, our third hypothesis indicates that:

\section{H3: There is significant negative impact for Commitment on the Employee Leave Intention.}

To examine the effect of Commitment on Employee Leave Intention, we use the simple linear regression analysis:

Table 6.

Panel A. Simple Linear Regression of Commitment on Employee Leave Intention

\begin{tabular}{ccccc}
\hline Model & $\mathrm{R}$ & $\mathrm{R}^{2}$ & Adjusted $\mathrm{R}^{2}$ & $\begin{array}{c}\text { Std. Error of the } \\
\text { Estimate }\end{array}$ \\
\hline 1 & 0.278 & 0.077 & 0.073 & 0.42869
\end{tabular}

Panel B. ANOVA Test to Examine the Overall Proposed Simple Linear Regression Model for Commitment and Employee Leave Intention

\begin{tabular}{lccccc}
\hline Model & Sum of Squares & $\mathrm{df}$ & Mean Square & $\mathrm{F}$ & Sig. \\
\hline Regression & 3.163 & 1 & 3.163 & 17.213 & 0.000 \\
Residual & 37.858 & 206 & 0.184 & & \\
Total & 41.021 & 207 & & &
\end{tabular}

Panel C. T- test to Examine the Significance of the Coefficients in the Simple Linear Regression Model for Commitment and Employee Leave Intention.

\begin{tabular}{lccccc}
\hline \multirow{2}{*}{ Model } & \multicolumn{2}{c}{$\begin{array}{c}\text { Unstandardized } \\
\text { Coefficients }\end{array}$} & $\begin{array}{c}\text { Standardized } \\
\text { Coefficients }\end{array}$ & \multirow{2}{*}{$\mathrm{T}$} & Sig. \\
\cline { 2 - 4 } Constant & $\mathrm{B}$ & Std. Error & Beta & & \\
\hline Commitment & 1.738 & 0.150 & & 11.612 & 0.000 \\
& -0.162 & 0.039 & -0.278 & -4.149 & 0.000
\end{tabular}

Table 6 Panel A shows that the Adjusted $\mathrm{R}^{2}$ is 0.073 , which means that the independent variable (Commitment) interprets $7.3 \%$ of the changes occurring in the dependent variable (Employee Leave Intention). Table 6 Panel B shows a statistically significant relationship between the independent variable (Commitment) and the dependent variable (Employee Leave Intention) which confirms the high explanatory power of the simple linear regression model statistically. Table 6 Panel $\mathrm{C}$ shows that the independent variable (Commitment) is significant and negatively related to the dependent variable (Employee Leave Intention). Therefore, we accept H3 stipulating that there is significant negative impact for Commitment on the Employee Leave Intention. 


\subsection{The Impact of Common Purpose on Employee Leave Intention}

Table 3 shows that the correlation between Common Purpose (Dimension 3) on Employee Leave Intention (ELI) ratings were medium $(-0.385, \mathrm{P}<0.01)$. As a result, our fourth hypothesis indicates that:

H4: There is significant negative impact for Common Purpose on the Employee Leave Intention.

To examine the effect of Common Purpose on Employee Leave Intention, we use the simple linear regression analysis:

Table 7.

Panel A. Simple Linear Regression of Common Purpose on Employee Leave Intention

\begin{tabular}{ccccc}
\hline Model & $\mathrm{R}$ & $\mathrm{R}^{2}$ & Adjusted $\mathrm{R}^{2}$ & $\begin{array}{c}\text { Std. Error of the } \\
\text { Estimate }\end{array}$ \\
\hline 1 & 0.385 & 0.148 & 0.144 & 0.41190
\end{tabular}

Panel B. ANOVA Test to Examine the Overall Proposed Simple Linear Regression Model for Common Purpose and Employee Leave Intention

\begin{tabular}{lccccc}
\hline Model & Sum of Squares & df & Mean Square & F & Sig. \\
\hline Regression & 6.070 & 1 & 6.070 & 35.778 & 0.000 \\
Residual & 34.951 & 206 & 0.170 & & \\
Total & 41.021 & 207 & & &
\end{tabular}

Panel C. T- test to Examine the Significance of the Coefficients in the Simple Linear Regression Model for Common Purpose and Employee Leave Intention.

\begin{tabular}{lccccc}
\hline \multirow{2}{*}{ Model } & \multicolumn{2}{c}{$\begin{array}{c}\text { Unstandardized } \\
\text { Coefficients }\end{array}$} & $\begin{array}{l}\text { Standardized } \\
\text { Coefficients }\end{array}$ & \multirow{2}{*}{$\mathrm{T}$} & Sig. \\
\cline { 2 - 4 } Constant & $\mathrm{B}$ & \multicolumn{2}{c}{ Std. Error } & \multicolumn{1}{c}{ Beta } & \\
\hline Common Purpose & 1.569 & 0.133 & & 11.804 & 0.000 \\
& -0.212 & 0.035 & -0.385 & -5.982 & 0.000
\end{tabular}

Table 7 Panel A shows that the Adjusted $\mathrm{R}^{2}$ is 0.144, which means that the independent variable (Common Purpose) interprets $14.4 \%$ of the changes occurring in the dependent variable (Employee Leave Intention). Table 7 Panel B shows a statistically significant relationship between the independent variable (Common Purpose) and the dependent variable (Employee Leave Intention) which confirms the high explanatory power of the simple linear regression model statistically. Table 7 Panel $\mathrm{C}$ shows that the independent variable (Common Purpose) is significant and negatively related to the dependent variable (Employee Leave Intention). Therefore, we accept H4 stipulating that there is significant negative impact for Common Purpose on the Employee Leave Intention.

\subsection{The Impact of Collaboration on Employee Leave Intention}

Table 3 shows that the correlation between Collaboration (Dimension 4) on Employee Leave Intention (ELI) ratings were medium $(-0.375, \mathrm{P}<0.01)$. As a result, our fifth hypothesis indicates that:

H5: There is significant negative impact for Collaboration on the Employee Leave Intention.

To examine the effect of Collaboration on Employee Leave Intention, we use the simple linear regression analysis:

Table 8.

Panel A. Simple Linear Regression of Collaboration on Employee Leave Intention

\begin{tabular}{ccccc}
\hline Model & $\mathrm{R}$ & $\mathrm{R}^{2}$ & Adjusted $\mathrm{R}^{2}$ & $\begin{array}{c}\text { Std. Error of the } \\
\text { Estimate }\end{array}$ \\
\hline 1 & 0.375 & 0.141 & 0.137 & 0.41367 \\
\hline
\end{tabular}


Panel B. ANOVA Test to Examine the Overall Proposed Simple Linear Regression Model for Collaboration and Employee Leave Intention

\begin{tabular}{lccccc}
\hline Model & Sum of Squares & $\mathrm{df}$ & Mean Square & $\mathrm{F}$ & Sig. \\
\hline Regression & 5.771 & 1 & 5.771 & 33.724 & 0.000 \\
Residual & 35.251 & 206 & 0.171 & & \\
Total & 41.021 & 207 & & & \\
\hline
\end{tabular}

Panel C. T- test to Examine the Significance of the Coefficients in the Simple Linear Regression Model for Collaboration and Employee Leave Intention.

\begin{tabular}{lccccc}
\hline \multirow{2}{*}{ Model } & \multicolumn{2}{c}{$\begin{array}{c}\text { Unstandardized } \\
\text { Coefficients }\end{array}$} & $\begin{array}{c}\text { Standardized } \\
\text { Coefficients }\end{array}$ & \multirow{2}{*}{$\mathrm{T}$} & \multirow{2}{*}{ Sig. } \\
\cline { 2 - 4 } & $\mathrm{B}$ & Std. Error & Beta & & \\
\hline Constant & 1.569 & 0.133 & & 11.804 & 0.000 \\
Collaboration & -0.212 & 0.035 & -0.385 & -5.982 & 0.000
\end{tabular}

Table 8 Panel A shows that the Adjusted $\mathrm{R}^{2}$ is 0.137 , which means that the independent variable (Collaboration) interprets $13.7 \%$ of the changes occurring in the dependent variable (Employee Leave Intention). Table 8 Panel B shows a statistically significant relationship between the independent variable (Collaboration) and the dependent variable (Employee Leave Intention) which confirms the high explanatory power of the simple linear regression model statistically. Table 8 Panel $\mathrm{C}$ shows that the independent variable (Collaboration) is significant and negatively related to the dependent variable (Employee Leave Intention). Therefore, we accept H5 stipulating that there is significant negative impact for Collaboration on the Employee Leave Intention.

\subsection{The Impact of Controversy with Civility on Employee Leave Intention}

Table 3 shows that the correlation between Controversy with Civility (Dimension 5) on Employee Leave Intention (ELI) ratings were medium $(-0.348, \mathrm{P}<0.01)$. As a result, our sixth hypothesis indicates that:

H6: There is significant negative impact for Controversy with Civility on the Employee Leave Intention.

To examine the effect of Controversy with Civility on Employee Leave Intention, we use the simple linear regression analysis:

Table 9.

Panel A. Simple Linear Regression of Controversy with Civility on Employee Leave Intention

\begin{tabular}{ccccc}
\hline Model & $\mathrm{R}$ & $\mathrm{R}^{2}$ & Adjusted $\mathrm{R}^{2}$ & $\begin{array}{c}\text { Std. Error of the } \\
\text { Estimate }\end{array}$ \\
\hline 1 & 0.348 & 0.121 & 0.117 & 0.41836
\end{tabular}

Panel B. ANOVA Test to Examine the Overall Proposed Simple Linear Regression Model for Controversy with Civility and Employee Leave Intention

\begin{tabular}{lccccc}
\hline Model & Sum of Squares & $\mathrm{df}$ & Mean Square & $\mathrm{F}$ & Sig. \\
\hline Regression & 4.966 & 1 & 4.966 & 28.371 & 0.000 \\
Residual & 36.056 & 206 & 0.175 & & \\
Total & 41.021 & 207 & & & \\
\hline
\end{tabular}

Panel C. T- test to Examine the Significance of the Coefficients in the Simple Linear Regression Model for Controversy with Civility and Employee Leave Intention.

\begin{tabular}{lccccc}
\hline \multirow{2}{*}{ Model } & \multicolumn{2}{c}{$\begin{array}{c}\text { Unstandardized } \\
\text { Coefficients }\end{array}$} & $\begin{array}{c}\text { Standardized } \\
\text { Coefficients }\end{array}$ & \multirow{2}{*}{$\mathrm{T}$} & \multirow{2}{*}{ Sig. } \\
\cline { 2 - 4 } & $\mathrm{B}$ & Std. Error & Beta & & \\
\hline Constant & 1.333 & 0.192 & & 6.932 & 0.000 \\
Controversy with Civility & -0.320 & 0.060 & -0.348 & -5.326 & 0.000 \\
\hline
\end{tabular}


Table 9 Panel A shows that the Adjusted $\mathrm{R}^{2}$ is 0.117 , which means that the independent variable (Controversy with Civility) interprets $11.7 \%$ of the changes occurring in the dependent variable (Employee Leave Intention). Table 9 Panel B shows a statistically significant relationship between the independent variable (Controversy with Civility) and the dependent variable (Employee Leave Intention) which confirms the high explanatory power of the simple linear regression model statistically. Table 9 Panel $\mathrm{C}$ shows that the independent variable (Controversy with Civility) is significant and negatively related to the dependent variable (Employee Leave Intention). Therefore, we accept H6 stipulating that there is significant negative impact for Controversy with Civility on the Employee Leave Intention.

\subsection{The Impact of Citizenship on Employee Leave Intention}

Table 3 shows that the correlation between Citizenship (Dimension 6) on Employee Leave Intention (ELI) ratings were medium $(-0.360, \mathrm{P}<0.01)$. As a result, our seventh hypothesis indicates that:

\section{H7: There is significant negative impact for Citizenship on the Employee Leave Intention.}

To examine the effect of Citizenship on Employee Leave Intention, we use the simple linear regression analysis:

Table 10.

Panel A. Simple Linear Regression of Citizenship on Employee Leave Intention

\begin{tabular}{ccccc}
\hline Model & $\mathrm{R}$ & $\mathrm{R}^{2}$ & Adjusted $\mathrm{R}^{2}$ & $\begin{array}{c}\text { Std. Error of the } \\
\text { Estimate }\end{array}$ \\
\hline 1 & 0.360 & 0.130 & 0.126 & 0.41627
\end{tabular}

Panel B. ANOVA Test to Examine the Overall Proposed Simple Linear Regression Model for Citizenship and Employee Leave Intention

\begin{tabular}{lccccc}
\hline Model & Sum of Squares & df & Mean Square & F & Sig. \\
\hline Regression & 5.325 & 1 & 5.325 & 30.728 & 0.000 \\
Residual & 35.697 & 206 & 0.173 & & \\
Total & 41.021 & 207 & & &
\end{tabular}

Panel C. T- test to Examine the Significance of the Coefficients in the Simple Linear Regression Model for Citizenship and Employee Leave Intention.

\begin{tabular}{lccccc}
\hline \multirow{2}{*}{ Model } & \multicolumn{2}{c}{$\begin{array}{c}\text { Unstandardized } \\
\text { Coefficients }\end{array}$} & $\begin{array}{c}\text { Standardized } \\
\text { Coefficients }\end{array}$ & \multirow{2}{*}{$\mathrm{T}$} & \multirow{2}{*}{ Sig. } \\
\cline { 2 - 4 } & $\mathrm{B}$ & Std. Error & Beta & & \\
\hline Constant & 1.751 & 0.111 & & 15.765 & 0.000 \\
Citizenship & -0.167 & 0.030 & -0.360 & -5.543 & 0.000
\end{tabular}

Table 10 Panel A shows that the Adjusted $\mathrm{R}^{2}$ is 0.126 , which means that the independent variable (Citizenship) interprets $12.6 \%$ of the changes occurring in the dependent variable (Employee Leave Intention). Table 10 Panel B shows a statistically significant relationship between the independent variable (Citizenship) and the dependent variable (Employee Leave Intention) which confirms the high explanatory power of the simple linear regression model statistically. Table 10 Panel $\mathrm{C}$ shows that the independent variable (Citizenship) is significant and negatively related to the dependent variable (Employee Leave Intention). Therefore, we accept $\mathrm{H} 7$ stipulating that there is significant negative impact for Citizenship on the Employee Leave Intention.

\subsection{The Impact of Change for the Common Good on Employee Leave Intention}

Table 3 shows that the correlation between Change for the Common Good (Dimension 7) on Employee Leave Intention (ELI) ratings were medium $(-0.408, \mathrm{P}<0.01)$. As a result, our eighth hypothesis indicates that:

H8: There is significant negative impact for Change for the Common Good on the Employee Leave Intention.

To examine the effect of Change for the Common Good on Employee Leave Intention, we use the simple linear regression analysis: 
Table 11

Panel A. Simple Linear Regression of Change for the Common Good on Employee Leave Intention

\begin{tabular}{ccccc}
\hline Model & $\mathrm{R}$ & $\mathrm{R}^{2}$ & Adjusted $\mathrm{R}^{2}$ & $\begin{array}{c}\text { Std. Error of the } \\
\text { Estimate }\end{array}$ \\
\hline 1 & 0.408 & 0.167 & 0.163 & 0.40734
\end{tabular}

Panel B. ANOVA Test to Examine the Overall Proposed Simple Linear Regression Model for Change for the Common Good and Employee Leave Intention

\begin{tabular}{lccccc}
\hline Model & Sum of Squares & df & Mean Square & F & Sig. \\
\hline Regression & 6.841 & 1 & 6.841 & 41.231 & 0.000 \\
Residual & 34.180 & 206 & 0.166 & & \\
Total & 41.021 & 207 & & & \\
\hline
\end{tabular}

Panel C. T- test to Examine the Significance of the Coefficients in the Simple Linear Regression Model for Change for the Common Good and Employee Leave Intention.

\begin{tabular}{lccccc}
\hline \multirow{2}{*}{ Model } & \multicolumn{2}{c}{$\begin{array}{c}\text { Unstandardized } \\
\text { Coefficients }\end{array}$} & $\begin{array}{c}\text { Standardized } \\
\text { Coefficients }\end{array}$ & \multirow{2}{*}{$\mathrm{T}$} & \multirow{2}{*}{ Sig. } \\
\cline { 2 - 4 } Constant & B & Std. Error & Beta & & \\
\hline Change for the Common Good & 1.142 & 0.190 & & 6.019 & 0.000 \\
& -0.361 & 0.056 & -0.408 & -6.421 & 0.000
\end{tabular}

Table 11 Panel A shows that the Adjusted $\mathrm{R}^{2}$ is 0.163 , which means that the independent variable (Change for the Common Good) interprets $16.3 \%$ of the changes occurring in the dependent variable (Employee Leave Intention). Table 11 Panel B shows a statistically significant relationship between the independent variable (Change for the Common Good) and the dependent variable (Employee Leave Intention) which confirms the high explanatory power of the simple linear regression model statistically. Table 11 Panel C shows that the independent variable (Change for the Common Good) is significant and negatively related to the dependent variable (Employee Leave Intention). Therefore, we accept H8 stipulating that there is significant negative impact for Change for the Common Good on the Employee Leave Intention.

\subsection{The Impact of Consciousness of Self on Employee Leave Intention}

Table 3 shows that the correlation between Consciousness of Self (Dimension 8) on Employee Leave Intention (ELI) ratings were medium $(-0.303, \mathrm{P}<0.01)$. As a result, our ninth hypothesis indicates that:

H9: There is significant negative impact for Consciousness of Self on the Employee Leave Intention.

To examine the effect of Consciousness of Self on Employee Leave Intention, we use the simple linear regression analysis:

Table 12.

Panel A. Simple Linear Regression of Consciousness of Self on Employee Leave Intention

\begin{tabular}{ccccc}
\hline Model & $\mathrm{R}$ & $\mathrm{R}^{2}$ & Adjusted $\mathrm{R}^{2}$ & $\begin{array}{c}\text { Std. Error of the } \\
\text { Estimate }\end{array}$ \\
\hline 1 & 0.303 & 0.092 & 0.087 & 0.42525
\end{tabular}

Panel B. ANOVA Test to Examine the Overall Proposed Simple Linear Regression Model for Consciousness of Self and Employee Leave Intention.

\begin{tabular}{lccccc}
\hline Model & Sum of Squares & df & Mean Square & F & Sig. \\
\hline Regression & 3.768 & 1 & 3.768 & 20.837 & 0.000 \\
Residual & 37.253 & 206 & 0.181 & & \\
Total & 41.021 & 207 & & & \\
\hline
\end{tabular}


Panel C. T- test to Examine the Significance of the Coefficients in the Simple Linear Regression Model for Consciousness of Self and Employee Leave Intention.

\begin{tabular}{lccccc}
\hline \multirow{2}{*}{ Model } & \multicolumn{2}{c}{$\begin{array}{c}\text { Unstandardized } \\
\text { Coefficients }\end{array}$} & $\begin{array}{c}\text { Standardized } \\
\text { Coefficients }\end{array}$ & \multirow{2}{*}{$\mathrm{T}$} & \multirow{2}{*}{ Sig. } \\
\cline { 2 - 4 } Constant & $\mathrm{B}$ & Std. Error & Beta & & \\
\hline Consciousness of Self & 1.380 & 0.214 & & 6.456 & 0.000 \\
& -0.276 & 0.060 & -0.303 & -4.565 & 0.000
\end{tabular}

Table 12 Panel A shows that the Adjusted $\mathrm{R}^{2}$ is 0.087, which means that the independent variable (Consciousness of Self) interprets $8.7 \%$ of the changes occurring in the dependent variable (Employee Leave Intention). Table 12 Panel B shows a statistically significant relationship between the independent variable (Consciousness of Self) and the dependent variable (Employee Leave Intention) which confirms the high explanatory power of the simple linear regression model statistically. Table 12 Panel $\mathrm{C}$ shows that the independent variable (Consciousness of Self) is significant and negatively related to the dependent variable (Employee Leave Intention). Therefore, we accept H9 stipulating that there is significant negative impact for Consciousness of Self on the Employee Leave Intention.

\section{Conclusion}

Our results indicate that Socially Responsible Leadership and its eight dimensions (Congruence, Commitment, Common Purpose, Collaboration, Controversy with Civility, Citizenship, Change for the Common Good and Consciousness of Self) have a significant negative impact on Employee Leave Intent. As a result, we can conclude that socially responsible leadership can be used to build a foundation for trusting fruitful relationships between organizations and stakeholders, in this case the firm's employees. Every single dimension of socially responsible leadership's eight dimensions led to a significant reduction in employee leave/turnover intention. This was all done while examining IT companies in a Middle Eastern/African country; Egypt.

One of the practical implications of the study is that it displays the need to focus on raising the awareness of companies to the importance of practicing social responsibility and how this is reflected on the performance of their employees and their intention to continue working for the company. Future research can focus on replicating this study in other sectors in Egypt besides the IT sector. It can also attempt to replicate the study on IT companies in other countries to test for changes. It would be interesting to examine whether the geographical location, culture and religion act as mediating variables and affect the results of the study. Culture, religion and geographical location act as external sources of influence on employee behaviors, including the turnover behavior, which influences employee perceptions towards the organization since each employee brings a piece of their 'outside world' into the workplace. Another interesting avenue for future research would be to consider the effect of leaders implementing the Leader Member Exchange Theory (LMX) on employee turnover. The leader member exchange theory focuses on the relationship between leaders and the members in their work groups. Furthermore, it is crucial for organizations to get a blueprint for alleviating turnover rates in their sectors and geographical locations.

One of the limitations of the study is that the results cannot be generalized to other sectors outside of the IT sector and to other countries besides Egypt. Another limitation is one that is common among all studies that rely on surveys, in our study the SRLS-R2, as a research tool. The soundness of our results will depend on the transparency and honesty of the responses of the 208 employees of Egyptian IT companies who participated in the study. The study would have benefited from the use of intercultural competence as a moderating variable.

\section{References}

Abbasi, S., \& Hollman, K. (2000). Turnover: the real bottom line. Public Personnel Management, 29(3), 333-342. https://doi.org/10.1177/009102600002900303

AlBattat, A., \& Som, A. (2013). Employee dissatisfaction and turnover crises in the Malaysian hospitality industry. International Journal of Business and Management, 8(5), 62-71. https://doi.org/10.5539/ijbm.v8n5p62

Allen, D., Shore, L., \& Griffeth, R. (2003). The role of perceived organizational support and supportive human resource practices in the turnover process. Journal of Management, 29, 99-118. https://doi.org/10.1177/014920630302900107

Bluedorn, A. (1978). A taxonomy of turnover. Academy of Management Review, 3, 647-651. https://doi.org/10.5465/amr.1978.4305918 
Dawley, D., Houghton, J.D., \& Bucklew N.S. (2010). Perceived organizational support and turnover intention: the mediating effects of personal sacrifice and job fit. Journal of Social Psychology, 150(3), 238-257.https://doi.org/10.1080/00224540903365463

Ertürk, A., \& Vurgun, L. (2015). Retention of IT professionals: examining the influence of empowerment, social exchange and trust. Journal of Business Research, 68(1), 34-46. https://doi.org/10.1016/j.jbusres.2014.05.010

Firth, L., Mellor, D., Moore, K., \& Loquet, C. (2007). How can managers reduce employee intention to quit? Journal of Managerial Psychology, 19(2), 170-187. https://doi.org/10.1108/02683940410526127

Foreman, E., \& Retallick, M. (2012). Undergraduate involvement in extracurricular activities and leadershipdevelopment in College of Agriculture and Life Sciences students. Journal of Agricultural Education, 53(3), 111-123. https://doi.org/10.5032/jae.2012.03111.

Griffith, J. (2003). Relation of principal transformational leadership to school staff job satisfaction, staff turnover, and school performance. Journal of Educational Administration, 42(3), 333-356. https://doi.org/10.1108/09578230410534667

Griffeth, R., Hom, P., \& Gaertner, S. (2000). A meta-analysis of antecedents and correlates of employee turnover: update, moderator tests, and research implications for the millennium. Journal of Management, 26, 463-488. https://doi.org/10.1177/014920630002600305

Hom, P., \& Griffeth, R. (1995). Employee Turnover. South-Western Series in Human Resources Management: Ohio, Cincinnati.

Hsu, J., Hsu, J., Huang, S., Leong, L., \& Li, A. (2003). Are leadership styles linked to turnover intentions: an examination in Mainland China? Journal of American Academy of Business, Cambridge, 3(1/2), 37-43. https://doi.org/10.1080/15280080802520529

Hu, S., \& McCormick, A. (2012). An engagement-based student typology and its relationship to college outcomes. Research in Higher Education, 53(7), 738-754. https://doi.org/10.1007/s11162-012-9254-7

Hughes, L., Avey, J., \& Nixon, D. (2010). Relationship between leadership and followers quitting intentions and job search behavior. Journal of Leadership and Organizational Studies, 20, 1-12. https://doi.org/10.1177/1548051809358698

Kleinman, C. (2004). The relationship between managerial leadership behaviors and staff nurse retention. Hospital Topics, 82(4), 2-9. https://doi.org/10.3200/HTPS.82.4.2-9

Komives, S., \& Dugan, J. (2010). Contemporary leadership theories. In Handbook of political and civic leadership. Eds. R. A. Couto. Los Angeles, CA: Sage. https://doi.org/10.4135/9781412979337.n14

Komives, S., \& Wagner, W. (2009). Leadership for a better world: Understanding the social change model of leadership development. San Francisco, CA: Jossey-Bass.

Liu, Z., Cai, Z., Li, J., Shi, S., \& Fang, Y. (2013). Leadership style and employee turnover intentions: a social identity perspective. Career Development International, 305-324. https://doi.org/10.1108/CDI-09-2012-0087

Long, C., Thean, L., Ismail, W., \& Jusoh, A. (2012). Leadership styles and employees' turnover intention: exploratory study of academic staff in a Malaysian college. World Applied Sciences Journal, 19(4), 575-581. https://doi.org/10.5829/idosi.wasj.2012.19.04.155

Long, C., \& Thean, L. (2011). Relationship between leadership style, job satisfaction and employees' turnover intention: a literature review. Research Journal of Business Management, 5(3), 91-100. https://doi.org/10.3923/rjbm.2011.91.100

Maak, T. (2007). Responsible leadership, stakeholder engagement, and the emergence of social capital. Journal of Business Ethics, 74(4), 329-334. https://doi.org/10.1007/s10551-007-9510-5

Maak, T. \& Pless, N. (2006). Responsible leadership in a stakeholder society: a relational perspective. Journal of Business Ethics, 66, 99-115. https://doi.org/10.1007/s10551-006-9047-z

Maertz, C., Jr., Griffeth, R., Campbell, N., \& Allen, D. (2007). The effects of perceived organizational support and perceived supervisor support on employee turn-over. Journal of Organizational Behavior, 28(8), 1059-1075. https://doi.org/10.1002/job.472

Mobley, W. (1982). Employee turnover, causes, consequences, and control. Reading, MA: Addison-Wesley. 
Northouse, P. (2007). Leadership: Theory and practice. Thousand Oaks, CA: Sage Publications.

O'Connell, M., \& Mei-Chuan, K. (2007). The cost of employee turnover. Industrial Management, 49(1), 14-19.

Pascarella, E. \& Blaich, C. (2013). Lessons from the Wabash National Study of Liberal Arts Education. Change: The Magazine of Higher Learning, 45(2), 6-15. https://doi.org/10.1080/00091383.2013.764257

Price, J. (2001). Reflections on the determinants of voluntary turnover. International Journal of Manpower, 22(7), 600-624. https://doi.org/10.1108/EUM0000000006233

Rhoades, L., \& Eisenberger, R. (2002). Perceived organizational support: a review of the literature. Journal of Applied Psychology, 87, 698-714. https://doi.org/10.1037//0021-9010.87.4.698

Rosch, D., \& Caza, A. (2012). The durable effects of short-term programs on student leadership development. Journal of Leadership Education, 11(1), 28-48. https://doi.org/10.12806/V11/I1/RF2

Siong, Z., Mellor, D., Moore, K., \& Firth, L. (2006). Predicting intention to quit in the call centre industry: does the retail model fit? Journal of Managerial Psychology, 21(3), 231243. https://doi.org/10.1108/02683940610659579.

Tett, R., \& Meyer, J. (1993). Job satisfaction, organizational commitment, turnover intention and turnover: path analyses based on meta-analytic findings. Personnel Psychology, 46(2), 259-293. https://doi.org/10.1111/j.1744-6570.1993.tb00874.x

Tyree, T. (1998). Designing an instrument to measure socially responsible leadership using the social change model of leadership development. Dissertation Abstracts International, 59(6), 1945, AAT 9836493.

Vandenberg, R., \& Nelson, J. (1999). Disaggregating the motives underlying turnover intentions: when do intentions predict turnover? Human Relations, 52(10), 1313-1336. https://doi.org/10.1023/A:1016964515185

Wells, J., \& Peachey, J. (2010). Turnover intentions: do leadership behaviors and satisfaction with the leader matter? Team Performance Management, 17, 23-40. https://doi.org/10.1108/13527591111114693

Yamane, T. (1967). Elementary Sampling Theory. New Jersey: Prentice Hall.

\section{Appendix}

All the questionnaire statements were obtained from the updated version of the Socially Responsible Leadership Scale (SRLS-R2) (retrieved from www.srls.umd.edu)

\section{Questionnaire Statements on the Socially Responsible Leadership Dimensions}

Table 1A. Analyzing the statements of the first dimension (Socially Responsible Leadership: Congruence)

\begin{tabular}{llcccc}
\hline No. & \multicolumn{1}{c}{ Statements } & Mean & Std. dev. & $\begin{array}{l}\text { Relative } \\
\text { weight }\end{array}$ & Rank \\
\hline 13 & My behaviours are congruent with my beliefs. & 3.5865 & 1.18453 & 71.73 & 7 \\
27 & It is important to me to act on my beliefs. & 3.8173 & 1.04733 & 76.35 & 2 \\
32 & My actions are consistent with my values. & 3.6923 & 1.11274 & 73.846 & 4 \\
52 & Being seen as a person of integrity is important to me. & 4.0481 & 1.01562 & 80.96 & 1 \\
64 & My behaviours reflect my beliefs. & 3.8077 & 1.10403 & 76.15 & 3 \\
65 & I am genuine. & 3.6250 & 1.22917 & 72.5 & 6 \\
69 & It is easy for me to be truthful. & 3.6442 & 1.14561 & 72.88 & 5 \\
& All statements & 3.7459 & 0.80787 & 74.92 & \\
\hline
\end{tabular}


Table 2A. Analyzing the statements of the second dimension (Socially Responsible Leadership: Commitment)

\begin{tabular}{|c|c|c|c|c|c|}
\hline No. & Statements & Mean & Std. dev. & $\begin{array}{l}\text { Relative } \\
\text { weight }\end{array}$ & Rank \\
\hline 23 & $\begin{array}{l}\text { I am willing to devote time and energy to things that } \\
\text { are important to me. }\end{array}$ & 3.9712 & 0.98743 & 79.42 & 1 \\
\hline 24 & I stick with others through the difficult times. & 3.5962 & 1.19999 & 71.92 & 5 \\
\hline 28 & I am focused on my responsibilities. & 3.8846 & 1.10605 & 77.69 & 2 \\
\hline 51 & I can be counted on to do my part. & 3.7885 & 1.07383 & 75.77 & 3 \\
\hline 53 & I follow through on my promises. & 3.5865 & 1.17634 & 71.73 & 6 \\
\hline \multirow[t]{2}{*}{54} & $\begin{array}{l}\text { I hold myself accountable for responsibilities I agree } \\
\text { to. }\end{array}$ & 3.7404 & 1.09452 & 74.808 & 4 \\
\hline & All statements & 3.7459 & 0.80787 & 74.92 & \\
\hline
\end{tabular}

Table 3A. Analyzing the statements of the third dimension (Socially Responsible Leadership: Common Purpose)

\begin{tabular}{|c|c|c|c|c|c|}
\hline No. & Statements & Mean & Std. dev. & $\begin{array}{l}\text { Relative } \\
\text { weight }\end{array}$ & Rank \\
\hline 14 & $\begin{array}{l}\text { I am committed to a collective purpose in those } \\
\text { groups to which I belong. }\end{array}$ & 3.4135 & 0.98893 & 68.27 & 8 \\
\hline 15 & $\begin{array}{l}\text { It is important to develop a common direction in a } \\
\text { group in order to get anything done. }\end{array}$ & 3.5769 & 1.07400 & 71.54 & 7 \\
\hline 19 & I contribute to the goals of the group. & 3.7596 & 1.15884 & 75.19 & 6 \\
\hline 31 & $\begin{array}{l}\text { I think it is important to know other people's } \\
\text { priorities. }\end{array}$ & 3.1827 & 1.18578 & 63.65 & 9 \\
\hline 35 & I have helped to shape the mission of the group. & 3.7596 & 1.23159 & 75.19 & 5 \\
\hline 37 & Common values drive an organization. & 3.7885 & 1.00888 & 75.77 & 3 \\
\hline 58 & I know the purpose of the groups to which I belong. & 3.8654 & 0.98351 & 77.31 & 1 \\
\hline 61 & $\begin{array}{l}\text { I work well when I know the collective values of the } \\
\text { group. }\end{array}$ & 3.8558 & 0.94709 & 77.12 & 2 \\
\hline \multirow[t]{2}{*}{68} & I support what the group is trying to accomplish. & 3.7596 & 1.08120 & 75.19 & 4 \\
\hline & All statements & 3.6624 & 0.80745 & 73.25 & \\
\hline
\end{tabular}

Table 4A. Analyzing the statements of the fourth dimension (Socially Responsible Leadership: Collaboration)

\begin{tabular}{|c|c|c|c|c|c|}
\hline No. & Statements & Mean & Std. dev. & $\begin{array}{l}\text { Relative } \\
\text { weight }\end{array}$ & Rank \\
\hline 10 & I am seen as someone that works well with others. & 3.6635 & 1.18453 & 73.27 & 4 \\
\hline 29 & $\begin{array}{l}\text { I can make a difference when I work with others on a } \\
\text { task. }\end{array}$ & 3.8558 & 1.08942 & 77.12 & 1 \\
\hline 30 & I actively listen to what others have to say. & 3.5288 & 1.22736 & 70.58 & 8 \\
\hline 42 & I enjoy working with others towards common goals. & 3.6250 & 1.08737 & 72.5 & 5 \\
\hline 48 & $\begin{array}{l}\text { Others would describe me as a cooperative group } \\
\text { member. }\end{array}$ & 3.5577 & 1.22634 & 71.15 & 7 \\
\hline 57 & Collaboration produces better results. & 3.7115 & 1.07383 & 74.23 & 3 \\
\hline 60 & $\begin{array}{l}\text { My contributions are recognized by others in the } \\
\text { groups I belong to. }\end{array}$ & 3.8269 & 1.04435 & 76.54 & 2 \\
\hline \multirow[t]{2}{*}{66} & I am able to trust the people with whom I work. & 3.6058 & 1.15820 & 72.12 & 6 \\
\hline & All statements & 3.6719 & .89030 & 73.44 & \\
\hline
\end{tabular}


Table 5A. Analyzing the statements of the fifth dimension (Socially Responsible Leadership: Controversy with Civility)

\begin{tabular}{|c|c|c|c|c|c|}
\hline No. & Statements & Mean & Std. dev. & $\begin{array}{l}\text { Relative } \\
\text { weight }\end{array}$ & Rank \\
\hline 1 & I am open to others' ideas. & 3.5192 & 1.15454 & 70.38 & 3 \\
\hline 2 & Creativity can come from conflict. & 2.9135 & 1.15563 & 58.27 & 9 \\
\hline 3 & I value differences in others. & 3.2981 & 1.12829 & 65.96 & 4 \\
\hline 5 & Hearing differences in opinions enriches my thinking. & 3.5769 & 1.15212 & 71.54 & 2 \\
\hline 7 & $\begin{array}{l}\text { I struggle when group members have ideas that are } \\
\text { different from mine. }\end{array}$ & 2.7308 & 1.22163 & 54.62 & 11 \\
\hline 11 & Greater harmony can come out of disagreements. & 2.7981 & 1.08907 & 55.96 & 10 \\
\hline 16 & I respect opinions other than my own. & 3.0962 & 1.19999 & 61.92 & 6 \\
\hline 21 & I am uncomfortable when someone disagrees with me. & 3.1538 & 1.34609 & 63.08 & 5 \\
\hline 25 & $\begin{array}{l}\text { When there is a conflict between two people, one will } \\
\text { win and the other will lose. }\end{array}$ & 3.0481 & 1.20690 & 60.96 & 7 \\
\hline 49 & I am comfortable with conflicts. & 2.9231 & 1.22528 & 58.46 & 8 \\
\hline \multirow[t]{2}{*}{62} & I share my ideas with others. & 3.7308 & 1.13129 & 74.62 & 1 \\
\hline & All statements & 3.1626 & 0.48364 & 63.25 & \\
\hline
\end{tabular}

Table 6A. Analyzing the statements of the sixth dimension (Socially Responsible Leadership: Citizenship)

\begin{tabular}{|c|c|c|c|c|c|}
\hline No. & Statements & Mean & Std. dev. & $\begin{array}{l}\text { Relative } \\
\text { weight }\end{array}$ & Rank \\
\hline 33 & I believe I have responsibilities to my community. & 3.6731 & 1.05356 & 73.46 & 2 \\
\hline 38 & I give time to make a difference for someone else. & 3.4038 & 1.21599 & 68.08 & 8 \\
\hline 40 & $\begin{array}{l}\text { I work with others to make my communities better } \\
\text { places. }\end{array}$ & 3.4808 & 1.21170 & 69.62 & 6 \\
\hline 44 & $\begin{array}{l}\text { I have the power to make a difference in my } \\
\text { community. }\end{array}$ & 3.7115 & 1.14354 & 74.23 & 1 \\
\hline 46 & I am willing to act for the rights of others. & 3.4808 & 1.26629 & 69.62 & 7 \\
\hline 47 & $\begin{array}{l}\text { I participate in activities that contribute to the common } \\
\text { good. }\end{array}$ & 3.5769 & 1.16048 & 71.54 & 4 \\
\hline 55 & $\begin{array}{l}\text { I believe I have a civic responsibility to the greater } \\
\text { public. }\end{array}$ & 3.5288 & 1.09418 & 70.58 & 5 \\
\hline \multirow[t]{2}{*}{67} & $\begin{array}{l}\text { I value opportunities that allow me to contribute to my } \\
\text { community. }\end{array}$ & 3.5769 & 1.10066 & 71.54 & 3 \\
\hline & All statements & 3.5541 & 0.96383 & 71.08 & \\
\hline
\end{tabular}


Table 7A. Analyzing the statements of the seventh dimension (Socially Responsible Leadership: Change for the Common Good)

\begin{tabular}{llcccc}
\hline No. & \multicolumn{1}{c}{ Statements } & Mean & Std. dev. & $\begin{array}{l}\text { Relative } \\
\text { weight }\end{array}$ & Rank \\
\hline 8 & & & & 57.50 & 8 \\
12 & Transition makes me uncomfortable. & 2.8750 & 1.18515 & 57.5 & 6 \\
& $\begin{array}{l}\text { I am comfortable initiating new ways of looking at } \\
\text { things. }\end{array}$ & 3.4712 & 1.14594 & 69.42 & 7 \\
17 & Change brings new life to an organization. & 3.4712 & 1.19546 & 69.42 & 2 \\
20 & There is energy in doing something a new way. & 3.6250 & 1.11370 & 72.5 & 9 \\
26 & Change makes me uncomfortable. & 2.7981 & 1.14950 & 55.96 & 10 \\
36 & New ways of doing things frustrate me. & 2.6058 & 1.20721 & 52.12 & 4 \\
39 & I work well in changing environments. & 3.5769 & 1.21736 & 71.54 & 3 \\
43 & I am open to new ideas. & 3.6154 & 1.17385 & 72.31 & 3 \\
45 & I look for new ways to do something. & 3.5865 & 1.22463 & 71.73 & 5 \\
50 & I can identify the differences between positive and & 3.7019 & 1.02980 & 74.04 & 1 \\
& negative change. & 3.3002 & 0.47703 & 66.00 &
\end{tabular}

Table 8A. Analyzing the statements of the eighth dimension (Socially Responsible Leadership: Consciousness of Self)

\begin{tabular}{|c|c|c|c|c|c|}
\hline No. & Statements & Mean & Std. dev. & $\begin{array}{l}\text { Relative } \\
\text { weight }\end{array}$ & Rank \\
\hline 4 & I am able to articulate my priorities. & 3.6058 & 1.21519 & 72.12 & 6 \\
\hline 6 & I have low self-esteem. & 2.1154 & 1.19020 & 42.31 & 9 \\
\hline 9 & I am usually self-confident. & 4.1154 & 1.01494 & 82.31 & 2 \\
\hline 18 & $\begin{array}{l}\text { The things about which I feel passionate have priority } \\
\text { in my life. }\end{array}$ & 3.7596 & 1.02618 & 75.19 & 4 \\
\hline 22 & I know myself pretty well. & 3.7885 & 1.02785 & 75.77 & 3 \\
\hline 34 & I could describe my personality. & 3.6635 & 1.03663 & 73.27 & 5 \\
\hline 41 & I can describe how I am similar to other people. & 3.3269 & .99702 & 66.54 & 7 \\
\hline 56 & Self-reflection is difficult for me. & 3.0096 & 1.10768 & 60.19 & 8 \\
\hline \multirow[t]{2}{*}{59} & I am comfortable expressing myself. & 4.1154 & 0.95612 & 82.31 & 1 \\
\hline & All statements & 3.5000 & 0.48867 & 70.0 & \\
\hline
\end{tabular}

Questionnaire Statements on the Employee Leave Intention

Table 9A. Analyzing the statements of Employee Leave Intention

\begin{tabular}{llcccc}
\hline No. & \multicolumn{1}{c}{ Statements } & Mean & Std. dev. & $\begin{array}{l}\text { Relative } \\
\text { weight }\end{array}$ & Rank \\
\hline 63 & I do what I can to avoid conflict. & 3.5481 & 1.23460 & 70.96 & 1 \\
70 & Effect on job continuation. & 2.0817 & 1.14969 & 41.63 & 6 \\
71 & I am thinking about leaving this organization. & 2.7212 & 1.21151 & 54.42 & 4 \\
72 & I am planning to look for a new job. & 3.1250 & 1.33107 & 62.5 & 2 \\
73 & I intend to ask people about new job opportunities. & 2.7837 & 1.14475 & 55.67 & 3 \\
74 & I do not plan to be in this organization much longer. & 2.5865 & 1.19266 & 51.73 & 5 \\
& All statements & 2.8077 & 0.66536 & 56.15 & \\
\hline
\end{tabular}

